РОЛЬ МОТИВАЦІЇ У ГОТОВНОСТІ ДИТИНИ ДО ШКІЛЬНОГО НАВЧАННЯ THE ROLE OF MOTIVATION IN THE CHILD'S READINESS FOR SCHOOL STUDDING

Удк 373.29:37.015.3:005.32(477.82)(045) DOI https://doi.org/10.32843/2663-60852019-18-3-10

\section{Козігора М.А.,}

викладач кафедри педагогіки, психології та окремих методик Луцького педагогічного коледжу
Стаття присвячена одній з актуальних проблем сьогодення - проблемі мотиваційної готовності дитини до шкільного навчання. Ця проблема останнім часом стала дуже популярною серед дослідників різних спеціальностей. Психологи, педагоги, фрізіологи вивчають і обгрунтовують критерії готовності до шкільного навчання, сперечаються про вік, із якого найдоцільніше починати навчання дітей у школі.

Сучасні умови життя та діяльності людини в Україні характеризуються кардинальними змінами у ссрері економіки, соціальних ситуаціях та освіти. Суспільство висуває нові вимоги до розвитку особистості, зокрема ії емоційної сфрери - формування ініціативності, сміливості, вміння приймати самостійні рішення, швидко адаптуватися до різних умов. Вирішення цього загального завдання тісно пов'язане з реалізацією Державної національної програми «Освіта» (Україна XXI cm.), «Діти України», Закону України «Про освіту», в яких визначено, що побудова демократичного суспільства, його розвиток значною мірою залежить від творчості, активності й емоційної стійкості його членів

Рефрормування в напрямі гуманізації сучасної системи освіти гостро порушує питання готовності дошкільників до навчання $у$ школі, оскільки че важливий крок у доросле життя, і від того, яким він буде, залежить здатність дитини адаптуватися до нових умов і реалізувати власні потенційні можливості. Для забезпечення ефективної адаптації дитини до шкільного навчання одним із важливих завдань психологічної служби дошкільного навчального закладу постає психологічний супровід готовності дітей до шкільного навчання, що грунтується на розумінні змісту, структури та критеріїв готовності до школи.

Зі вступом дитини до школи настає абсолютно новий етап ї̈життя, i до цього етапу вона повинна бути достатньо підготовленою, бути готовою виконувати серйозну діяльність, що дає їй не тільки нові права, але і покладає нелегкі обов'язки. Маленький школяр вправі розраховувати на пошану тих, хто оточує його на заняттях, і сам зобов'язаний систематично виконувати всі завдання вчителя, поводитися відповідно до шкільних правил незалежно від того, хоче він ५ьОго чи ні.
Ключові слова: мотивація, готовність до шкільного навчання, психологічна готовність, школяр, мотиви навчання.

The article deals with one of the pressing problems of today - the problem of motivational readiness of a child to school. This problem has recently become very popular with researchers in various specialties. Psychologists, educators, physiologists study and substantiate the criteria for school readiness, argue about the age from which it is most appropriate to start teaching children in school.

The present conditions of life and human activity in Ukraine are characterized by dramatic changes in the sphere of economy, social situations and education. Society puts forward new requirements for the development of the individual, in particular his emotional sphere - forming initiative, courage, ability to make independent decisions, quickly adapt to different conditions. The solution to this general problem is closely related to the implementation of the State National Program "Education" (Ukraine of the 21st Century), "Children of Ukraine", the Law of Ukraine "On Education", which stipulates that the construction of a democratic society, its development depends to a great extent on creativity , activity and emotional stability of its members.

Reforming the humanization of the modern education system strongly raises the issue of preschoolers' readiness to study at school, as it is an important step in adulthood, and on what it will be, depends on the child's ability to adapt to new conditions and realize his or her potential. In order to ensure effective adaptation of the child to school education, one of the important tasks of the psychological service of the preschool institution is psychological support of the children's readiness for school education, which is based on an understanding of the content, structure and criteria of school readiness.

With the introduction of the child to school comes a whole new phase of his life and by this stage he should be sufficiently prepared. Above all, it must be prepared to undertake serious activities that give it not only new rights but also difficult responsibilities. The little schoolboy is entitled to count on those who surround him in class and is obliged to systematically carry out all the tasks of the teacher, to act according to school rules, whether he wants it at the moment or not. Key words: motivation, readiness for schooling, psychological readiness, schoolboy, motives of learning.
Постановка проблеми у загальному вигляді. Сучасні умови життя та діяльності людини в Україні характеризуються кардинальними змінами у сфері економіки, соціальних ситуаціях та освіти. Суспільство висуває нові вимоги до розвитку особистості, зокрема ії̈ емоційної сфрери - формування ініціативності, сміливості, вміння приймати самостійні рішення, швидко адаптуватися до різних умов. Реформування в напрямі гуманізації сучасної системи освіти гостро порушує питання готовності дошкільників до навчання у школі, оскільки це важливий крок у доросле життя, і від того, яким він буде, залежить здатність дитини адаптуватися до нових умов і реалізувати власні потенційні можливості.

Поняття готовності дитини до школи багатогранне. Воно охоплює фрізіологічну, психологічну (особистісну, соціальну, інтелектуальну) та педагогічну зрілість дитини. Успішне розв'язання питань розвитку особистості дитини, підвищення ефективності процесу навчання, подальше професійне становлення та соціальну самореалізацію особис- 
тості багато в чому визначає те, наскільки враховують рівень фрізіологічної, психологічної та педагогічної готовності дитини до шкільного навчання.

На сучасному етапі суспільного розвитку важливим вважають медичний підхід до готовності до школи, що зумовлено значним погіршенням стану здоров'я дітей, зниженням їх фрункціональних можливостей і збільшенням вимог школи. Основними медичними критеріями готовності до шкільного навчання $є$ : рівень біологічного розвитку дитини (зріст, наявність постійних зубів); стан здоров'я на момент вступу до школи; динаміка захворюваності за попередній рік.

Аналіз останніх досліджень і публікацій. Широко й багатогранно подано психологічний підхід до розгляду готовності до шкільного навчання (Л.І. Божович, Л.А. Венгер, А.Л. Венгер, Л.С. Виготський, А.В. Запорожець, В.С. Мухіна і багато інших). Однак досі в сучасній психології немає чіткої визначеності поняття психологічної готовності до шкільного навчання [1, с. 19].

Зарубіжні дослідження шкільної зрілості переважно спрямовані на створення відповідних тестів, у роботах же радянських психологів Л.І. Божович і Д.Б. Ельконіна міститься глибоке теоретичне опрацьовування питань психологічної готовності до школи 3 погляду змістовного обґрунтування необхідного і достатнього нижчого рівня актуального розвитку першокласника [2, с. 32].

У теоретичних роботах Л.І. Божович основний акцент робився на значення афективно-потребної сорери у фрормуванні особистості дитини. 3 цих же позицій розглядалася психологічна готовність до школи, тобто найбільш важливим визнавався мотиваційний план. Були виділені дві групи мотивів навчання:

- широкі соціальні мотиви учіння або мотиви, пов'язані 3 потребами дитини у спілкуванні 3 іншими людьми, у їх оцінці і схваленні, з бажанням учня зайняти певне місце в системі доступних йому суспільних відносин;

- мотиви, пов'язані безпосередньо з навчальною діяльністю, або пізнавальні інтереси дітей, потреба в інтелектуальній активності й оволодінні новими уміннями, навиками і знаннями.

Дитина, готова до школи, хоче вчитися і тому, що їй хочеться зайняти певну позицію в товаристві людей, а саме позицію, що відкриває доступ у світ дорослості, і тому, що у неї є пізнавальна потреба, яку вона не може задовольнити вдома. Сплав цих двох потреб сприяє виникненню нового ставлення дитини до навколишнього середовища, названого Л.І. Божович «внутрішньою позицією школяра». Цьому новоутворенню Л.І. Божович надавала дуже велике значення, вважаючи, що «внутрішня позиція школяра» може виступати як критерій готовності до шкільного навчання [2, с. 36]. Але слід відзначити, що і «внутрішня позиція» і широкі соціальні мотиви учіння - явища суто історичні, адже система суспільного виховання і навчання, що існує в нашій країні, припускає декілька ступенів дорослішання:

- ясла, дитячий сад - дошкільне дитинство: до дітей ставляться, як до малюків;

- школа - зі вступом до школи дитина встає на першу сходинку дорослішання, тут починається іiї підготовка до самостійного дорослого життя; саме таке значення надається школі в нашому суспільстві;

- вища школа або робота - дорослі люди. Таким чином, школа $\epsilon$ сполучною ланкою між дитинством і дорослістю, причому якщо відвідини дошкільної установи $є$ необов'язковими, то відвідини школи досі були строго обов'язковими, і діти, досягаючи шкільного віку, розуміють, що школа відкриває їм доступ до дорослого життя. Звідси з'являється бажання піти вчитися в школу, щоб зайняти нове місце в системі суспільних відносин.

Виділення не вирішених раніше частин загальної проблеми. Незважаючи на реформу освіти та впровадження навчання 3 шестирічного віку, лишається актуальним педагогічний підхід до визначення готовності до шкільного навчання. Основними педагогічними критеріями готовності дитини до шкільного навчання $€$ : навички читання, писання та рахування.

Однак варто враховувати, що спеціалізовані школи, гімназії, ліцеї висувають вимоги до першокласника, які значно перевищують можливості шестирічної дитини, що $€$ неправомірним. Так, Н.М. Стадненко та ін. зазначають, що навички читання та письма потрібно формувати у школі, а у дошкільний віковий період треба закладати лише передумови, які дають змогу дитині більшменш швидко оволодіти цими навичками у школі $[1$, c. 26].

Мета статті - теоретично обґрунтувати проблему психологічної готовності до навчання дитини дошкільного віку.

Виклад основного матеріалу. Соціальні мотиви учіння радянських дітей, що вступали до школи, визначалися тією конкретною історичною обстановкою, в якій жили діти. Тоді школа була обов'язковою для здобування середньої освіти, причому вона була єдиною загальноосвітньою, що виключало існування привілейованих навчальних закладів, але саме тому сам по собі вступ до школи, хоч і означав для дитини перехід на новий віковий ступінь, нічим не відрізняв іії від решти однолітків, а тому соціальні мотиви учіння були пов'язані з самою діяльністю учіння.

Зазвичай в афрективно-потребній сорері дитини, що вступає до школи, представлені різні мотиви учіння, але будь-який один може домінувати. Розберемо послідовно різні випадки домінування того або іншого мотиву. 
Сьогодні знову з'являються ліцеї та гімназії, а єдина загальноосвітня школа перестає існувати. У зв'язку з цим незабаром можуть з'явитися нові соціальні мотиви учіння, оскільки ряд навчальних закладів виділяються у престижні.

До соціальних мотивів учіння належать мотиви, пов'язані 3 потребою дитини зайняти нову соціальну позицію, а також із потребою у спілкуванні на новому рівні, що припускає оцінку і схвалення людей.

Дослідження Е.О. Смірнової, присвячене комунікативній готовності шестирічних дітей до шкільного навчання, дає цікаве пояснення, чому саме до кінця дошкільного віку у дітей з'являється потреба у спілкуванні з дорослим на новому рівні [2, с. 41]. Комунікативна готовність до школи розглядається як результат певного рівня розвитку спілкування. У дослідженні наголошується, що в дошкільному віці зустрічаються три фрорми спілкування: ситуативно-ділова, позаситуативно-пізнавальна і позаситуативно-особова. Перша з них, ситуативно-ділова, характеризується співпрацею з дорослим у грі, при освоєнні дій із різними предметами і т. д. Дорослий виступає тут для дитини як учасник спільної діяльності і, відповідно, на перший план виходять його ділові якості й уміння. Основним засобом спілкування $є$ наочні дії. Ситуативно-ділове спілкування переважно характерне для дітей до 4 років. Позаситуативно-пізнавальна форма спілкування знаменується першими пізнавальними питаннями дитини, адресованими дорослому. На цьому етапі розвитку спілкування дорослий стає для дитини джерелом нових знань, не завжди прив'язаних до конкретної ситуації. Ця фрорма спілкування переважає у віці 4-5 років.

У міру дорослішання старших дошкільників дедалі більше починають привертати події, що відбуваються у світі людей, а не речей. Людські відносини, норми поведінки стають важливим моментом у змісті спілкування дитини з дорослим. Так народжується найбільш складна в дошкільному віці впозаситуативно-особова форма спілкування, що зазвичай складається лише до кінця дошкільного віку.

Дорослий, як і раніше, є для дітей джерелом нових знань, і діти, як і раніше, потребують його визнання і пошани. Проте для дитини стає дуже важливо, щоб його ставлення до тих або інших подій збіглося зі ставленням дорослого. Потреба у взаєморозумінні та співпереживанні дорослого є відмітною особливістю такої фрорми спілкування.

У разі домінування соціальних мотивів учіння дитина прагне в школу, щоб зайняти в суспільстві нову позицію, позицію школяра. Пізнавальна потреба виражена у неї слабо, а тому в школі її насамперед цікавлять не знання, які дає вчитель, а строго виконання ролі учня, заданою новою соціальною позицією. У загальних рисах першоклас- ник знає, що він повинен робити як учень, тобто як він повинен виконувати роль учня [3, с. 261].

Така структура мотиваційної сорери дозволить учневі успішно справлятися з своїми обов'язками доти, поки для нього буде приваблива соціальна позиція школяра. Але як тільки ця позиція стане для нього звичною і йому вже не потрібно буде підтвердження, що він добре справляється зі своєю роллю, домінування соціальних мотивів навчання, похвала вчителя перестане чинити мотивуючу дію.

Якщо доти в учня не сорормуються власне навчальні мотиви, пов'язані безпосередньо 3 навчальною діяльністю, або якщо у нього не виникнуть нові соціальні мотиви типу отримання в майбутньому певної спеціальності, для якої необхідний хороший шкільний атестат, то учень може стати невстигаючим.

Зазначимо, що первинне домінування соціального мотиву навчання може привести до формування пізнавальної мотивації шляхом зсуву мотиву на мету. Цей механізм утворення нових мотивів був описаний А.Н. Леонтьєвим [3, с. 262]. Так, спочатку учень добре виконує завдання тому, що хоче отримати похвалу вчителя. Він знає, що знання йому необхідні, але цей мотив є таким, що не реально діє, а тільки розуміється, оскільки у дитини немає достатньої пізнавальної потреби. Мотивом, що реально діє, є потреба в похвалі вчителя. Але тривале добросовісне виконання навчальних завдань заради гарної оцінки вчителя може привести до того, що учень зацікавиться самим змістом навчальної діяльності, й у нього з'явиться пізнавальна потреба. Таким чином, мотив, що тільки розуміється, стане реальним, таким, що діє, і з'явиться нова опосередкована потреба. Іншими словами, пізнавальна потреба опосередковується потребою отримати схвалення вчителя.

Цих дітей, швидше за все, можна охарактеризувати як допитливих. Вони хочуть багато знати, нерідко приходять у перший клас, вже вміючи читати і писати, а в школу прагнуть, щоб дізнатися ще більше. Але якщо на уроках їм стає нецікаво, то вони можуть відвернутися і зайнятися сторонньою справою. Буває і так - на уроках учень уважно слухає новий матеріал, що викликає у нього інтерес, а вдома не виконує домашнє завдання, тому що повторювати вже засвоєний матеріал йому нудно. Оскільки у дитини слабо розвинені соціальні мотиви учіння, у неї не спостерігається прагнення добре виконувати обов'язки учня, як цього вимагає її нова соціальна позиція. Якщо в такого учня слабо розвинена мотивація досягнення, то він незабаром, незважаючи на добре розвинену пізнавальну потребу, може почати відставати в навчанні.

Говорячи про домінування окремо взятого мотиву, не треба забувати, що таким чином створюється якась абстрактна модель, що дозволяє краще зрозуміти роль того або іншого мотиву 
в афрективно-потребній сорері, але лише дійсність, що приблизно відображає, в якій абсолютне домінування якогось одного мотиву майже не зустрічається. Повноцінна навчальна мотивація повинна включати і пізнавальні мотиви, і широкі соціальні мотиви, але індивідуальність кожної дитини виявляється в домінуванні якогось 3 указаних мотивів усередині навчальної діяльності. Отже, можна говорити, що в дослідженнях Л.І. Божович, присвячених психологічній готовності до школи, як нижчий актуальний рівень психічного розвитку, необхідне і достатнє спершу навчання в школі, було запропоновано новоутворення, назване нею «Внутрішня позиція школяра» [3, с. 267]. Це психологічне новоутворення виникає на рубежі дошкільного і молодшого шкільного віку, або в період кризи 7 років, і є сплавом двох потреб - пізнавальної та потреби у спілкуванні з дорослими на новому рівні. Саме поєднання цих двох потреб дозволяє дитині включитися в навчальний процес як суб'єкт діяльності, що виражається у свідомому фрормуванні та виконанні намірів і цілей або, іншими словами, довільній поведінці учня. Майже всі автори, котрі досліджують психологічну готовність до школи, приділяють довільності особливе місце в проблемі, що вивчається. $€$ думка, що слабкий розвиток довільності - головний камінь спотикання психологічної готовності до школи. Але в якому ступені повинна бути розвинена довільність до початку навчання в школі - питання, слабо опрацьоване в літературі.

Висновки. Готовність до школи визначається соціальною й емоційною зрілістю дитини. Вона виражається в умінні контактувати 3 іншими людьми (дітьми та дорослими), дотримуватися прийнятих у суспільстві правил поведінки, уміти грати в ігри за правилами, самому їх дотримуватися і стежити за їх дотриманням іншими учасниками.

Мотивація до навчання: знання тоді засвоюються міцно, коли вони добуті самостійно. Те, що дитині повідомляють, може пройти повз ії свідомість; але те, про що вона здогадалася сама, її власне відкриття, залишається в пам'яті назавжди. Тому заняття для підготовки дітей старшого дошкільного віку до навчання у школі повинні проводитися в ігровій, захоплюючій фрормі з використанням практичних завдань і творчих вправ. Таким чином, у дитини формується пізнавальний інтерес, бажання вчитися.

\section{БІБЛІОГРАФІЧНИЙ СПИСОК:}

1. Максименко С. Готовність дитини до навчання. Київ : Мікрос-СВС, 2003. 112 с.

2. Маркова А.К. Формирование мотивации учения в школьном возрасте. Москва : Просвещение, 1983. $96 \mathrm{C}$

3. Мухина В.С. Возрастная психология. Москва : Академия, 1999. 456 с. 